\title{
The Application Research of Project Learning in English Teaching Du Rong
}

\author{
School of Foreign Studies, Xi'an University, 710065
}

Keywords: Project Learning; English Teaching; Application; Research

\begin{abstract}
In recent years, with the continuous progress of educational reform, English teaching has been prevalent in colleges and universities and English has become a compulsory course in college English major. But this course is more abstract, obscure and so on, so how to learn this course well has become a problem that need to solve urgently for the colleges and universities. Therefore, it needs teachers brainstorming who come from college and looks for breakthrough to enhance students' interest in learning English. After a series of experiments, it is found that the project learning can effectively improve the students' interest and passion for learning English. Project learning is mainly student-based, through a series of projects, which makes students accustomed to English teaching mode. At the same time, it can also stimulate students' passion for learning English. Ultimately it not only can improve students' understanding and learning ability of English, but also enhance the feelings and cooperation between students and teachers to improve classroom teaching efficiency.
\end{abstract}

\section{Introduction}

The colleges and universities began to set the English course from long time ago. And the main purpose is to develop students' awareness to use English, improve their understanding of the English language and finally can be separated from Chinglish. Because of the influence of traditional Chinese education, English teaching has always been a teacher-oriented in class and students learn English by reciting words and sentences or doing various English questions. It is the existence of this teaching mode that makes students lack the awareness of the daily use of English, which is not conducive to colleges and universities to carry out this course. English is more complex to learn than others, so it is hard to learn English well just through reciting words and doing some exercises, which may make students lose their interest for learning English. At present, in order to change this situation, the colleges and universities have began to implement project learning. The development of project learning can make English teaching get rid of the traditional teaching and make the course more diversified and interesting to improve students' interest for learning English.

\section{Problems in College English Teaching at the Present Stage}

Teaching Method is too Single. At present, there are a series of problems in English teaching in the colleges and universities. It is mainly influenced by traditional teaching, which makes the English teaching method too single. At the same time, school also neglects the training of students' English skills in English teaching. Now the ways that students learn English mainly are reciting words, reading text and translating words and sentences. This way of learning makes students can not grasp the key point and can not remember what they learned, so the efficiency of students learning English is relatively low. Meanwhile, in English teaching, the teacher did not develop a reasonable and effective teaching program. Under the influence of the traditional teaching program, teachers generally believe that only need to find new words, teach grammar and explain the article, which can help students to learn English well. However, it is counterproductive and deeply affect the initiative and enthusiasm of students for learning English.

Teachers' Thought Need to Be Improved. Children who grow up in China often bring Chinese fixed thinking mode to English learning and it will give their learning to a certain impact when they learn English because of regional culture, customs and other effects. At present, the teachers' thought is too old and can not follow the development of the times, so they still use the previous 
simple teaching methods in English teaching. The old teaching method lacks communication with students, ignores the importance of foreign cultural history to the students, and ultimately affects students' understanding of English materials.

\section{The Basic Content of Project Learning}

The Theoretical Basis of Project Learning. Project learning, as the name suggests, is to learn English through the project. Project learning mainly refers to that students alone accept a relatively independent project under the guidance of the teacher and then finish the whole process by themselves, such as collection of information, design, implementation of projects and so on. Every detail in the course of the project needs students to be responsible for and understand personally, so that it can help students to learn and grow effectively. The biggest feature of project learning is that students are the main body and teachers guide them. This way of learning can put students into the active position to promote students to take the initiative to learn knowledge and take the initiative to absorb and understand the English culture. At the same time, it can also stimulate students' interest for learning English and ultimately change students' view on the English course, which is conducive to students to take the initiative to learn English.

The Main Features of Project Learning. The first feature is student-centered. In recent years, with Chinese social and economic progress and development, people's life philosophy and living standards are changing. Teachers are the main body in most of the traditional education mode and students are in a passive state in the classroom. With the continuous changes of society in these years, we can find that the traditional teaching mode has appeared a big crisis. At present, how to explore the teaching mode of students as the main body has become the mainstream of education. The new project learning fully adapt to the current educational thinking, which mainly takes students as the main body and takes the initiative to improve students' interest in learning. Besides, there is also a large change in the teaching mode. Students have a relatively free learning environment now than before and teachers stimulate students' passion to learn and explore knowledge by asking questions. For example, teachers can set up a voice project that the different departments on the tongue can send a different voice, and then let students take the initiative to explore which parts can issue what kind of sound. This will not only allow students to take the initiative to learn pronunciation, but also have a in-depth understanding of how to pronounce, which is conducive to improve students' understanding of knowledge.

The second feature is to mobilize students' motivation to learn. Many colleges and universities tend to start the English language course when students are freshman. However, students at this stage just free from the college entrance examination and they want to have a easy life. Besides, English itself is more difficult to learn and understand. Therefore, if want to improve the quality of school language teaching, teachers need to mobilize actively the motivation of students to learn. English is more difficult to compare with other disciplines and it is more difficult to learn, especially for students with poor English foundation, so teachers can help students to learn English through project learning. Project learning emphasizes student-oriented and pays attention to group learning. Teachers will allocate students reasonably, which is conducive to learn from each other to enhance thinking and understanding ability and the feelings between students.

The third feature is to use a variety of tools to learn. Project learning, as a new teaching mode, its main attraction is not only the change of teaching mode, but also combines a series of new ideas and techniques. Traditional English teaching too much depends on the school textbooks and information, which often makes English more boring. At present, the new project learning is very good to make up for this shortcoming. During the project learning process, teachers can use multimedia technology, such as video, animation, to make textbook knowledge more flexible, which is more helpful for students to remember and learn.

The fourth feature is to help to focus on students' dynamics. Project learning takes students as the main body and emphasizes the role of students. Project learning is that a few students form a group to learn and they can speak freely in the group to express their views. In this process, teachers can know the progress of students to learn and the degree of knowledge to facilitate, and then 
teachers sum up the weak links of students and stress the key point again in the classroom. This will not only improve the students' knowledge, but also enhance the feelings between teachers and students. For example, teachers can carry out a dictation once a week. After understand the situation of students' dictation, teachers can provide ideas and suggestions to students according to the actual situation to enhance students' confidence to learn English.

\section{The Role of Applied Project Learning in College English Teaching}

Change the Backward Teaching Mode and Enhance Students' Sense of Autonomy. In the process of imparting knowledge, the most concerned of teachers is whether the teaching method can improve students' learning efficiency. In recent years, the project learning is a very good innovation of teaching method. With the continuous progress of society, people also have ideas on the educational methods and the education sector also puts forward new requirements for traditional education. Therefore, this requires teachers and schools to improve and enhance the existing educational methods and ultimately meet the requirements. The emergence of project learning method is an innovation of the existing educational methods, which is a good incentive for students to further study English linguistics. At the same time, teachers are also making the appropriate changes, abandon the traditional form of education, make a new design and operation and ultimately achieve good results.

Stimulate Students' Interest in Learning and Have Good Practical Significance. Project learning method is usually composed of four parts, such as content, action, atmosphere and conclusion. Content refers to topics of the project and topics related to life are the best material. Such as skills and sentences that foreign friends daily use, which is conducive to understand and master for students in the process of learning. The teaching materials from life have more practical significance and students can link skills and life together to strengthen the personal memory and improve the efficiency of learning. In addition, the main purpose of the project learning method is to strengthen students' listening and speaking skills. The development of project learning method enables students to better study and solve the difficulties encountered in the learning process, which can improve their interest in learning English and the times of using English. The effective development of the project learning method not only improves students' ability to express English, but also enriches students' western culture.

\section{The Practical Application of Project Learning in English Teaching}

Choose the Subject. It will involve a lot of learning points in English teaching. In this case, teachers will need to choose a specific subject and design curriculum for students. Besides, teachers should allow students to understand as much as possible and to take the initiative to seize the focus of the course in the teaching of English. At the same time, before the project learning is carried out, teachers need to set the relevant rules for students and help students to clear their learning objectives so as to ensure the normal progress of the later project learning.

Make a Good Plan before the Subject Study. After the project learning carried out, students will face a large number of topics. At this time, teachers need to develop a good learning plan for students according to their actual situation and do the appropriate preparation to ensure the normal development of the project learning. When students do the project learning tasks, they can choose the members freely within the class to form a group and choose their own topics of interest, so as to start a series of discussions and researches.

Make a Clear Division of Labor for Team Members. Before English project learning starts, students need to understand that everyone is a member of the group and should clear their own learning tasks in accordance with the requirements from the teacher, so as to ensure the effective implementation of the project. After get the tasks from teachers, students should collect and organize information based on the tasks and will put forward doubts or comments in the classroom to teachers after learning, which will help teachers and students to progress together and ensure the quality of teaching. 
Make a Summary before the Report. In the process of project learning, if students complete the task that assigned by teachers, teachers will need to develop reporting time according to the situation of the entire group, so that students can summarize and report the project within the specified time together. Teachers find out the lack or the problem according to their reports and tell students timely, so that they can understand and then correct it. Correspondingly, teachers should also encourage students to learn from others, which is the only way to be able to complete a satisfactory and qualified project learning materials.

Make a Good Evaluation. Project learning is applied to English teaching, so that teachers need to sum up and evaluate work at the end of each project. Only in this way can point out the lack of students and the places need to improve, so as to further improve the project.

\section{Conclusion}

As mentioned above, with the progress and development of society, the innovation of teaching methods has become the inevitable result of development. Therefore, the project learning applied to English teaching is the inevitable way of modern teaching innovation, which has an important role to enhance students' learning and understanding ability. Therefore, in the course of the development of the times, teachers should follow the pace of the times, apply the project learning to the daily study of students and cultivate comprehensive talents actively for society.

\section{Reference}

[1] B.R. Wang. The Application of Project Learning in College English Teaching under the Network Environment - A Study on the Action of Non-English Majors in 2008 from Northeastern University[J]. Journal of Northeastern University (Social Science Edition), 2010, 02: $168-172+188$.

[2] S.F. Guo, J.Y. Wu, Z. Ming, J.Z. Quan, J. Xia and F.P. Yan. The Application of "Project Learning" Teaching Mode in Medical English Teaching[J]. Journal of Bengbu Medical College, 2013, 11: 1493-1496.

[3] Y.M. Liu. Research on the Application of Project Learning in Business English Teaching under the Network Environment[J]. Trade Union Forum (Journal of Shandong Institute of Trade Unions' Management Cadre College), 2011, 03: 122-123.

[4] B. Han. On the Motivation and Cultivation of Learning Motivation in College English Teaching - The Application of Psycholinguistics in Foreign Language Teaching[J]. Journal of Liaocheng University (Social Science Edition), 2004, 02: 180-182.

[5] G.H. Mo and B. He. Research on the Application of Project Learning Method in Public English Teaching in Higher Vocational Education[J]. Journal of Jiangsu Architectural Vocational and Technical College, 2016, 02: 63-66.

[6] B.R. Wang. The Application of Project Learning in College English Teaching under the Network Environment - A Study on the Action of Non-English Majors in 2008 from Northeastern University[J]. Journal of Northeastern University (Social Science Edition), 2010, 02: $168-172+188$.

[7] Z.H. Xiao and G.R. Dai. The Application of Corpus in Language Teaching - A Case Study of Chinese English Learners' Passive Sentence Acquisition[J]. Journal of Zhejiang University (Humanities and Social Sciences), 2010, 04: 189-200.

[8] S.F. Guo, J.Y. Wu, Z. Ming, J.Z. Quan, J. Xia and F.P. Yan. The Application of "Project Learning" Teaching Mode in Medical English Teaching[J]. Journal of Bengbu Medical College, 2013, 11: 1493-1496.

[9] B. Han. On the Motivation and Cultivation of Learning Motivation in College English Teaching - The Application of Psycholinguistics in Foreign Language Teaching[J]. Journal of Liaocheng University (Social Science Edition), 2004, 02: 180-182.

[10]S. Li, X.D. Zhao and R. Zhao. On Student - centered Teaching Mode and College English Teaching Reform[J]. Journal of Northeastern University (Social Science Edition), 2005, 02: 
144-147.

[11]Y.M. Liu. Research on the Application of Project Learning in Business English Teaching under the Network Environment[J]. Trade Union Forum (Journal of Shandong Institute of Trade Unions' Management Cadre College), 2011, 03: 122-123.

[12]H.J. Wang, J. Dong and F. Su. The Application of Cognitive Linguistic Theory in English Vocabulary Teaching[J]. Journal of Inner Mongolia Agricultural University (Social Science Edition), 2011, 04: 139-141. 